\title{
THE CLASSICAL ASSOCIATION OF SOUTH AFRICA: JULY 1966 - JANUARY 1971
}

\author{
W J Henderson (University of Johannesburg)
}

The first decade of the history of the Classical Association of South Africa (CASA) was documented in two previous articles. ${ }^{1}$ The present article continues the account.

\section{Seventh CASA conference, 20-23 July 1966, Stellenbosch}

\subsection{Conference proceedings}

At the Opening Meeting, the Chairperson, Prof. Farrer, welcomed the 30 delegates, and in particular Prof. Guite from Rhodesia, ${ }^{2}$ to the special conference organised to coincide with the centenary celebrations of the University of Stellenbosch, which was congratulated on the achievement. Several members could not attend due to illness, absence abroad or unforeseen circumstances; for Prof. Petrie the distance was too far to travel ${ }^{3}$ and illness prevented Prof. Haarhoff from attending the opening meeting, but he was present at later sessions of the conference and delivered a paper.

In his report, the Chairperson, Prof. Farrer, informed the meeting that membership now stood at just over 200, that the regional branches were functioning well, and that Mrs Els of the Western Province Branch would represent the Association at the FIEC conference in Geneva in September. Due to the earlier date of the CASA conference, no financial reports on the finances and Acta Classica were tabled. The Treasurer did, however, inform the meeting that there was a balance of about R1790. ${ }^{4}$ At the suggestion of Prof. Van Rooy, the Executive Committee designated particular persons to introduce the discussions of papers.

The Closing Meeting was attended by 23 members, including Prof. Haarhoff. ${ }^{5}$ The Treasurer was authorised to make a fixed deposit of R1000 out of the Association's funds. The wording of the constitution regarding Acta Classica was clarified, to the effect that members received copies of the journal bearing the dates of the years for which they paid subscriptions, and that members studying abroad and exempted from subscriptions would receive Newsletter but not Acta Classica. An invitation to hold the next conference at the University of Potchefstroom ${ }^{6}$ was accepted, and it was decided to schedule this for a date in February 1969.

$1 \quad$ Henderson 2004 and 2005. To avoid unnecessary repetition, the office-bearers on committees are indicated as follows: $\mathrm{C}=$ Chairperson, $\mathrm{VC}=$ Vice-Chairperson, $\mathrm{S}=$ Secretary, $\mathrm{T}=$ Treasurer, ST = Secretary-Treasurer, AM = Additional Member(s).

2 On the name-changes since then, see Henderson 2004:89 n. 3; 2005:109 n. 1.

3 In accordance with a decision at the Closing Meeting, a letter of appreciation, together with the luncheon menu signed by delegates, was sent to Prof. Petrie; S to Petrie, 9 August 1966; a letter of appreciation and good wishes was subsequently sent to Prof. Petrie by the outgoing secretary: Baumbach to Petrie, 18 June 1969; reply from Petrie to Baumbach, 25 June 1969.

4 A financial statement for the period 01/12/1964 to 31/01/1967 was later published in NL 12.1 (1967) 14-15, reflecting a balance of R1815.

$5 \quad$ Haarhoff had retired in 1957; cf. Smuts 1957.

6 Now the University of the North-West. 
An invitation was also received to hold the conference thereafter at the University of the Orange Free State. During the general discussion, Prof. Haarhoff mentioned that he had received an encouraging reply from the State President, Mr C $\mathrm{R}$ Swart, who expressed concern over the decline of Classics. Prof. Haarhoff suggested that the new Executive Committee should consider the possibility of inviting the President to some Classical function or other. The Treasurer announced that there was a deficit of R45 for the conference because some members now preferred to remain outside the pool system used at previous conferences. Prof. Dietrich raised the matter of locally produced school books for Latin, and a committee was formed, consisting of Prof. Dietrich (convener), Prof. Smuts and $\mathrm{Mr}$ Hewitt, to investigate the matter.

The meeting elected the new Executive Committee: Prof. Farrer (C), Prof. De Kock (VC), Ms Baumbach (S), Mr Els (T), Prof. Coetzee (AM). The following were appointed as liaison officers to represent the various universities and schools: Dr Conradie (Stellenbosch), Ms B Lewis (Port Elizabeth), Mr M Henderson (Rhodes), Mr J Barkhuizen (Orange Free State), Mr Saddington (Witwatersrand), Mr Kriel (Pretoria), Mr P Hasse (Unisa), Mr P Snyman (Western Cape), Mr Van der Walt (Zululand), Mr Drijepondt (University College of the North), Mr J Coetzee (University College for Indians) and Prof. Guite (Rhodesia).

During the conference eleven papers were read and a symposium held on Classical Civilisation courses. Delegates were treated to an excursion to the old winefarms Vredenburg and Meerlust (21 July), a luncheon as guests of the Rector of the university (Prof. H B Thom), a walking tour of the old Cape Dutch buildings in the town, and a light supper on the farm Old Nectar (22 July). ${ }^{7}$

\subsection{Administration 1966-1969}

\subsubsection{General}

On 6 September 1966, the Prime Minister, Dr H F Verwoerd, was assassinated in Parliament. The Chairperson, Prof. Farrer, sent a message of sympathy on behalf of the Association to Dr Muller, Honorary Vice-President of CASA and Minister of Foreign Affairs, who thanked the Association on behalf of the government. ${ }^{8}$

At this stage the archive of the Association was growing to proportions that made the transference of documents to the newly-appointed secretary problematic. Only the necessary documents (minutes, constitution, correspondence, membership lists) and administrative information were passed on to the new secretary, Ms Baumbach. Prof. Richards suggested to her that material be kept in the archive to preserve the "history" of the Association in case "when the Association is 50 or 100 years old, they might be glad to have such information available.",

\footnotetext{
$7 \quad$ Minutes of the Opening Meeting, 20 July 1966; Editor 1966:158-60; 159-61 (English). This was the last time reports of conference proceedings were published in Acta Classica.

$8 \quad$ Muller to C, 3 October 1966; C to S, 12 October 1966.

9 Richards to S, 26 January 1967 (quote translated from Afrikaans).
} 
The new treasurer also faced a problem: there was no local branch of the Nasionale Bouvereniging where CASA's account was held. The Executive Committee was asked to approve an alternative, which was duly done. ${ }^{10}$

The matter of new letterheads was complicated by the fact that the original photo of the Nike-coin that had been agreed on had gone missing. The most suitable method of reproduction of the image would also have to be established. ${ }^{11}$

A letter was received from Prof. B R Rees of University College, Cardiff on behalf of the Classical Association of Great Britain, in which he gave a summary of their AGM and activities, invited a report of CASA's activities for publication in the 1968 number of Proceedings, announced the next General Meeting to be held at Royal Holloway College, University of London, from 8-11 April 1969, invited colleagues from South Africa to attend, and introduced his successor, Dr J G Landels of Reading University. ${ }^{12}$ After further correspondence, a report detailing CASA's Executive Committee and the papers delivered at the biennial conference at Stellenbosch (1966) was sent to Prof. Rees in time for inclusion in Proceedings. ${ }^{13}$

\subsubsection{The position of Classics}

Concern regarding the changing position of Classics in almost every country of the world was articulated and discussed at a "Colloquium on the Present State and Future Prospects of the Classics in Education" during the Fourth International Congress of Classical Studies, held at the University of Pennsylvania on 24-29 August 1964. Delegates from fifteen countries participated. A second colloquium was held in the Institute of Classical Studies of the University of London on 19-22 August 1965. Prof. M C J Putnam compiled a report on the proceedings of the second colloquium, an Afrikaans version of which was published in Newsletter. ${ }^{14}$

In South Africa a debate arose in the Onderwysblad of the Transvaalse Onderwysersvereniging on the merits and demerits of Latin as a school subject. ${ }^{15}$ The hard facts of the matter were that in 1955, 19,2\% of children in South African schools were learning Latin, but by 1965 the figure had dropped to $12 \% .{ }^{16}$ It was, however, encouraging that the actual numbers of such pupils were increasing. ${ }^{17}$ A more positive attitude was advocated and teachers were to be complimented for their dedication and encouraged in their endeavours. ${ }^{18}$

10 Conradie to S, 18 February 1967; S to Farrer, Coetzee and De Kock, 21 February 1967; Farrer to S, 25 February 1967; Coetzee to S, 27 February 1967. The account was transferred to the S A Permanent Building Society, while a R1000 deposit was left with the Nasionale Bouvereniging: Conradie to S, 11 April 1967; T to S, 3 May 1967.

11 Richards to S, 20 January 1967.

12 Rees to S, 24 April 1968.

13 Landels to S, 24 May 1967; S to Rees, undated; Rees to S, 27 May 1967.

14 Benade 1966. See also the account of Smuts 1968b on the situation in the USA.

15 Smuts 1966a; Viljoen 1966.

16 Cf. Henderson 2005:109 n. 3.

17 Smuts 1966b:21.

$18 \quad$ Kriel 1967. 
In response to a newspaper report concerning a proposed bill to abolish Latin for lawyers, ${ }^{19}$ the Chairperson prepared a statement to submit to the Department of Justice, but it was decided to wait for the forthcoming conference to formulate a resolution. ${ }^{20}$ Shortly afterwards, the Association of Law Societies, at a meeting of its council at the Victoria Falls attended by 28 South African and 10 Rhodesian (Zimbabwean) delegates, passed a resolution supporting the retention of Latin for admission to the legal profession. The meeting also expressed regret at the declining number of schools offering Latin and urged the government to encourage the training of Latin teachers. ${ }^{21}$ Just over three weeks later, another voice came out in support of Latin as a requirement for Law. In his address at the opening of the new Supreme Court Buildings in Kimberley, Chief Justice L C Steyn stated that without Latin the preservation and development of the South African common law could not be maintained; that he was convinced that at least judges, advocates and law teachers should have a knowledge of Latin in order to perform their tasks properly; and that concessions could be made for magistrates and attorneys. ${ }^{22}$

\subsubsection{Visitors}

Mr Russell Meiggs of Balliol College, Oxford, who was to be a guest lecturer at the University of the Witwatersrand and guest speaker at the conference, unfortunately fell ill and had to cancel his visit. There was still uncertainty surrounding the proposed visit of Prof. Albrecht Dihle. ${ }^{23}$ At the conference there was a motion to invite Prof. Lambrechts of Gent in terms of the Cultural Treaty between SA and Belgium.

Prof. H D F Kitto visited the University of Natal (Durban) from 21 May to 16 June 1967 as a guest of the Department of Drama. Its head, Prof. Elizabeth Sneddon, informed Prof. De Kock that Prof. Kitto had expressed the wish to meet colleagues in Classics and was willing to go on a lecture tour of the universities. A programme was hurriedly organised: Pretoria University and Unisa (22-24 May), Witwatersrand University (25-26 May), Kruger National Park (27-28 May), Natal University, Durban (29 May-3 June), Pietermaritzburg (6-7 June), Rhodes University (8-10 June), Universities of Cape Town and Stellenbosch (11-15 June) ${ }^{24}$ Visits were also paid to the University College for Indians (2 June) ${ }^{25}$ and University College of Zululand (5 June) ${ }^{26}$ Each centre provided for his accommodation and paid his travel expenses, to which the Association also contributed (R51.60). ${ }^{27}$

Natal Witness - SAPA, 24 April 1968.

C to S, 16 May 1968 (with handwritten statement); 23 June 1968; C to S, 11 July 1968.

Die Burger, 12 September 1968; Smuts 1968a:4, 26.

Die Burger, 6 November 1968; Smuts 1968c.

Minutes of the Opening Meeting, 20 July 1966, item 6(e).

Two of his lectures appeared in Newsletter; Kitto 1967a, b.

Now incorporated into the University of KwaZulu-Natal.

Now the University of Zululand.

VC to T, 4 August, 1967; VC to S, 5 August 1967; S to T, 23 August 1967; S to Coetzee, 23 August 1967; Coetzee to S, 6 September 1967. 
Dr Mary Smallwood (Queen's University, Belfast) was visiting lecturer in the Department of Classics at the University of Cape Town during the second semester of 1967. On 11 September, under the auspices of the local branch of CASA, she gave a public lecture on the historical background to the New Testament, and on October 2, 11 and 16 she gave lectures on "The Jews in Rome", "The Roman government of Palestine" and "The Jews in Egypt and Cyrene", arranged by the Department of Extra-mural Studies of the university. ${ }^{28}$

At the suggestion of Mr Saddington, the secretary of the Classical Association of Central Africa requested advance information on scholars visiting South Africa in order to include Salisbury in the itinerary. The Association was also invited to submit reports of its activities for publication in the Proceedings of the African Classical Associations. $^{29}$

\subsubsection{Acta Classica}

A request came from the National Central Library in London expressing interest in subscribing to Acta Classica, including earlier volumes. ${ }^{30}$ Requests had come from publishers to review books by overseas scholars, but the policy of the Association was to review only works by local authors. It was suggested that a motion be proposed at the next conference to include a limited number of reviews of works by foreign Classicists. ${ }^{31}$

\subsubsection{Next conference}

The Executive Committee began to discuss arrangements for the next conference. The first dates proposed (4-7 February 1969) proved to be too late for the host university, Potchefstroom, and 28-31 January was chosen. ${ }^{32}$ Invitations to deliver papers were sent out and the programme compiled. It was suggested that there be only one paper (for example a longer one) for the evening sessions, perhaps followed by general discussion on the papers read that day; that three papers could be placed in the morning sessions; that sufficient time should be allowed for discussion, but that the speaker introducing the discussion (provided in advance with a copy of the paper) and moving the vote of thanks should be brief and ad rem; and that time should be allowed for informal contact. ${ }^{33}$ There was a suggestion to hold a $30 \mathrm{~min}$. discussion on the merits and demerits of prose composition and unseen translation, in view of the tendency in Britain and Europe to place more emphasis on the reading of Greek and Latin texts. ${ }^{34}$

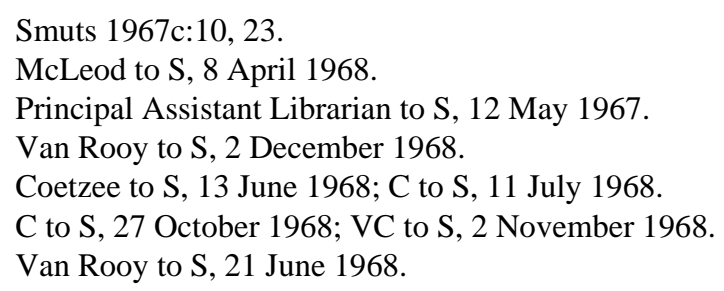


Due to the fact that three other conferences were scheduled to take place in the same period, accommodation was arranged in one of the university residences. ${ }^{35}$

\subsection{The Regional Organisations}

\subsubsection{The Transvaal Region}

Three successful meetings were organised in the second half of $1966 .{ }^{36}$ On 30 July 1966 a Latin Reading Competition was held in Pretoria - the first of what was to prove a popular and successful part of the branch's future activities. 190 children participated before an audience of about 500 pupils and teachers. Scenes from Alicia in Terra Mirabili were performed by pupils and Latin renderings of some popular hits presented. The branch enjoyed publicity in the press and on radio, and a recording of readings from Latin was subsequently made by Messrs Benade, Hasse and Kriel for use by schools. At the first local meeting of the branch at the University of Potchefstroom on 12 August 1966 Mr H W Simpson gave an illustrated talk on Rome to an audience of university and school teachers and pupils. At the next meeting of the branch, at the University of the Witwatersrand on 17 September 1966, Mr Saddington spoke on Horace's mythologising of the familiar and Mr P J Coetzee on hermeneutic principles in reading a Latin text. A scheme was introduced whereby university lecturers were invited to give talks in schools. ${ }^{37}$

On 17 June 1967 a Teachers' Conference was held at the University of the Witwatersrand. Fifty persons attended. Miss D Turner spoke on the integration of the school library; Mr De Villiers on the new syllabus and Mr Engelbrecht on the ideal reader, shortcomings of the examination paper and the integration of reading-matter and grammar. The same subject was discussed at Potchefstroom on 14 June 1967. The annual reading competition was held at the Johannesburg College of Education on 12 August. Various schools presented items in Latin and a film "The Spirit of Rome" was shown. At the annual general meeting on 23 September, at the University of Pretoria, Prof. Coetzee gave a talk on form and function in Latin, and Prof. Van Rooy on the palace of Knossos (with slides).

During 1968 three meetings were held. On 15 June a conference at Unisa attracted an audience of 55. The theme was the background study to the prescribed texts. The annual reading competition took place on 17 August, after which Prof. D F Mostert (Law Faculty, Pretoria University) spoke on the importance of Latin for the jurist. $^{38}$ At the annual general meeting (attended by 23 persons) on 28 September Prof. Maurach spoke on Vergil's Catalepton VIII, and Dr Benade on Homeric motifs in Vergil's Aeneid V-VIII. Mr De Villiers was re-elected as Chairperson, and Dr Kriel, who had taken over from Mr P J Maree in 1968, was elected as SecretaryTreasurer. $^{39}$

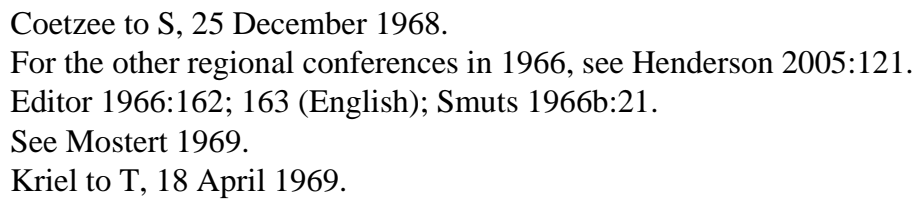




\subsubsection{The Western Cape Region}

The branch, in collaboration with the Department of Classics at the University of Cape Town and the Department of Latin at the University of Stellenbosch organised a Classical Study Tour for pupils in the Matriculation class or aged 16 or over. The Cape Education Department gave its approval and the information was published in the Cape Teachers' Gazette on 17 November 1966. Ms Baumbach sent a letter to various colleagues to promote the project among school principals and arrange for introductory talks to pupils in their areas. ${ }^{40}$ Some replies were positive, ${ }^{41}$ others hesitant, ${ }^{42}$ and in the end the tour was cancelled due to lack of response from school children.

About 75 teachers attended the first conference of 1967, on 3 June. The meeting started with a symposium on Rome's debt to Greece, with Prof. Paap chairing a panel consisting of Proff. Haarhoff, Van Rensburg and Smuts, Drr. Hugo and Conradie, Misses Baumbach and S M Bruwer, and Messrs G van W Kruger, M. Apthorp and Van Gysen. The debate first raged around Homer's influence on Vergil, and then questions from the floor were answered. A slide-show on Greek and Roman theatres was then presented by Proff. Paap and Smuts and Ms Baumbach. After lunch Prof. G Pulvermacher (College of Music, UCT) gave a lecture on ancient Greek music and played a recorded example. Finally, lecturers and students from Cape Town performed a rehearsed reading of scenes from Menander's Dyskolos and students from Stellenbosch from Plautus' Miles Gloriosus. ${ }^{43}$

A second conference was held at the University of Stellenbosch on 21 September 1967 and drew an audience of 40. Prof. Smuts spoke on non-literary Roman writers, ${ }^{44}$ and a panel discussed audio-visual aids. Prof. Hugo illustrated the use of maps, $\mathrm{Mr} \mathrm{F}$ du Toit the use of tables to summarise the subjunctive in subordinate clauses, and Prof. Smuts the use of the language laboratory (followed by a visit to the newly-installed one at the university). After a cena Romana a recording was played of pupils reading passages of Latin and a choir sang some Latin songs. The new committee was constituted as follows: Prof. Hugo (C), Prof. Pope (VC), Mr Potgieter (S-T), Mr Atkinson (Assist. S-T), Misses Baumbach, Bruwer and E. Cartwright, Sr M. O’Sullivan, Mr J M Powis and Prof. Smuts (AM). ${ }^{45}$

Three conferences were held during 1968 with audiences ranging between 35 and 55, of whom about half were members of CASA. The first conference was held on 20 April 1968 and devoted to the new syllabus for matriculation Latin, introduced by Messrs Powis and Potgieter. The next conference, on 15 June, was devoted to Ovid: the Heroides, Ars Amatoria, Epistulae ex Ponto, Tristia, Fasti, and the

40 Baumbach to Farrer, Erasmus, Richards, Viljoen, Gonin, De Kock, Coetzee, Dietrich, Hewitt, 23 November 1966.

41 Conradie to Baumbach, 21 October 1966; Els to Baumbach, 25 October 1966; Coetzee to Baumbach, 28 October 1966; Dietrich to Baumbach, 28 November 1966;

42 Farrer to Baumbach, 21 October 1966, on grounds that only children from richer homes would be able to participate, and that the tour would be more beneficial to second-year students.

See Smuts 1967a.

See Smuts 1967d.

Smuts 1967b, e. 
Metamorphoses were dealt with by Prof. Pope, Dr Hugo, Mr Atkinson and Dr Conradie. At the last meeting on 17 August Ms Baumbach spoke on the development of Latin before and after the Classical period, Prof. Pope on the pronunciation and reading of Latin verse, and Prof. Smuts on the latest developments in the teaching of Latin in the USA. At this meeting official leave was taken of Prof. Pope who had been associated with the Department of Classics at UCT for 20 years. The new committee was chosen: Dr Hugo (C), Mr Powis (VC), Mr Potgieter (S), Mr Atkinson (Assist. S-T), Prof. Smuts, Misses Baumbach, C P Hazel and James, and Dr Conradie $(\mathrm{AM}){ }^{46}$

\subsubsection{The Natal Region}

The branch was established on 18 March 1967 at a conference of Latin teachers held at Kearsney College. The following office-bearers were elected: Prof. De Kock (C), Mr W J Henderson (S), Mrs L B Goodyer (T) and Messrs E C Smith, J F Reece and J J Coetzee (AM). ${ }^{47}$ Mr Henderson gave a talk on Horace, Carm. 3.13. ${ }^{48}$ At a second meeting, attended by 40 persons at the University of Natal (Durban) on 14 October, the programme consisted of a symposium on the pronunciation of Latin, introduced by Messrs Henderson and Whiteley, and a talk, with colour slides, on Crete and Mycenae by $\mathrm{Mr}$ Jack Evans, nephew of Sir Arthur Evans and resident outside Pietermaritzburg. ${ }^{49}$

\subsubsection{The Eastern Cape Region}

At a combined meeting of the Port Elizabeth and Grahamstown local branch committees held in Grahamstown on 19 June 1967, it was decided that the status quo of the separate committees be maintained for 1967; that at least one meeting would be held in each centre to which members of the other centre would be invited; that as from 1968 there would still be separate branch committees, but that from these two committees an Eastern Cape Regional Branch committee would be chosen, with the chairperson alternating between the two centres.

The inaugural meeting of the Port Elizabeth Branch was held on 24 April 1967, with Prof. Erasmus as Chairperson and Ms Lewis as Secretary-Treasurer. Mr C J Botha spoke on "Some thoughts on the teaching of Latin today", and Mr G Bauer on "Perhaps one approach to teaching Latin". ${ }^{50}$ The next meeting, a combined one held on 19 June, took the form of a symposium, during which several of the university lecturers spoke on background material to five Latin authors prescribed for school. At the third meeting, on 16 September and also combined, an attempt was made to arrange talks on a wider variety of subjects of interest to the general public: Prof. Dietrich spoke on the ideals and practices of Greek physical education and sports; Mr A $\mathrm{H}$ de Vries, Afrikaans writer, gave an entertaining talk on modern

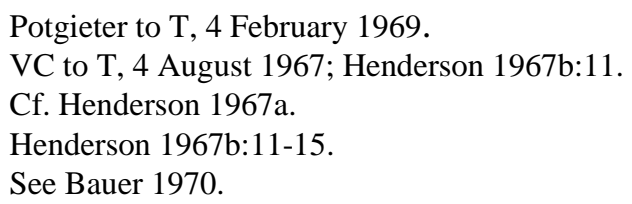


survivals of ancient Greek customs and superstitions; and Prof. Erasmus spoke on the changing picture of Rome. Poor attendance and lack of interest among teachers and general public were noted. ${ }^{51}$

The next annual general meeting of the Port Elizabeth Branch took place on 14 March 1968, and Dr P J du Plessis was elected Chairperson and Ms Lewis Secretary-Treasurer. ${ }^{52}$ On this occasion Dr Du Plessis read a paper entitled "Momente en motiewe in die Oedipus Rex". At the first meeting of the new committee, Prof. Erasmus was co-opted as Additional Member. The main argument for the formation of a separate branch committee was the amount of travelling involved between Port Elizabeth and Grahamstown (200 km) just to attend regional committee meetings. It was decided to appoint a committee member of each centre as liaison officer. The Grahamstown committee approved of the resolution at a committee meeting on 4 April 1968, and Ms Lewis and Mr K O Matier, Secretary-Treasurer of the Grahamstown branch, were designated. ${ }^{53}$ Two joint meetings were held, on 17 May (Port Elizabeth) and 7 June 1968 (Grahamstown).

Despite personal letters explaining the nature and functions of the Association and setting out the programme for the year, the response from teachers was discouraging. However, at the meeting on 17 May Prof. Guy Butler spoke on Shakespeare and the Classics before an audience of over 100, including colleagues from Grahamstown, members of the local division of the South African Council for English Education, and a theatre appreciation group. Some wished their names to be added to the mailing list, while others asked for information and application forms. An "open letter to all friends of the Classics", outlining the aims, activities and membership of CASA, was circulated at the meeting. On 1 August Prof. P J J Olivier spoke on "Die invloed van die Romeinse reg op die Suid-Afrikaanse reg"; this was followed on 2 August by an evening meeting attended by about 80 pupils and teachers. At the last meeting of the year, on 29 October, Dr Du Plessis gave the "presidential" address on "Contemporary thoughts on translation". 54

The Grahamstown Branch held its annual general meeting at Rhodes University on 29 March 1968. The following office-bearers were elected: Prof. Dietrich (C), Mr Hewitt (VC), Mr Matier (S-T), Mrs A Dietrich, Mrs V Jenkins, Mr W D Chalmers, and Mr G Fourie (AM). Mr Hewitt gave an illustrated talk on “Travels in Greece 1967”. On 7 June 1968 a symposium for teachers was held which was attended by lecturers and teachers from both Grahamstown and Port Elizabeth. The symposium was introduced by Mr Chalmers on the new Joint Matriculation Board syllabus, and short papers were delivered on authors included in the syllabus:

51 Lewis to S, 23 November 1967; circular, 29 April 1968. A provisional programme for 1968 and an invitation to join CASA were included. Among the items envisaged were the recorded readings of Latin poets and prose-writers, followed by a Latin reading competition; a prize for the best translation into Latin of any popular song which could be sung to the original tune; and a dramatised play-reading of a Greek or Latin comedy, preceeded by an introduction on ancient comedy.

52 Ms Lewis resigned to pursue her studies in England, and was replaced by Mr U. Strack; Lewis to S, 8 August 1969.

53 Matier to S, 14 May 1968; report dated 6 February 1969, item 2, tabled at conference.

$54 \quad$ Lewis to S, 14 June 1968; Matier, report to conference, item 3; Lewis to S, 11 November 1968. 
Apuleius (Prof. Dietrich), Tibullus (Mr Hewitt) and Horace (Mr Matier). Editions of all the authors as well as books on ancient history were on display. The annual Latin reading competition, in which pupils from Grahamstown schools also participated, was held on 4 August. The year's activities were rounded off with the "presidential" address entitled "Petronius: satyr or satirist?" by the Chairperson, Prof. Dietrich, on 18 September 1968. Visits to schools and close contact with teachers and pupils were producing an encouraging response. ${ }^{55}$

\subsubsection{The Orange Free State Region}

After a period of inactivity due to changes in staff, this branch held a meeting at the university on 14 September 1968. There were 22 persons present, some from Virginia and Welkom. The new committee consisted of Mr C P Venter (C), Prof. Richards (VC), Mr J F G Cilliers (S), Miss D M M van den Heever and Mrs A Snyman (AM). Talks were given on the new Free State syllabus (Mr Venter), recent views on translation into Latin (Miss Watson), and new approaches to teaching Latin in the USA (Miss W. Coetzee). ${ }^{56}$

\section{Eighth CASA conference, 28-31 January 1969, Potchefstroom}

\subsection{Conference proceedings}

The Opening Meeting of the conference took place at the University of Potchefstroom on 28 January 1969. The Chairperson, Prof. Farrer, welcomed the 32 delegates and congratulated the university on the jubilee of its Theological College. Prof. Petrie had sent a letter with apologies for his absence.

The meeting took note of the reply from the S A Library Association to the effect that in future material ordered on Inter-Library loan would be provided as photocopies for which a fee would be levied. After much debate on the matter of submitting advance summaries of conference papers to Newsletter, it was decided that, instead, a provisional programme of the conference should be sent out a year before the conference and select reading lists of papers published in Newsletter.

Lively discussion arose around Article 11 of the constitution which required that contributions from universities should be pooled for the benefit of all, but especially junior, delegates. ${ }^{57}$ Prof. Coetzee pointed out that not all the universities were in favour of the ruling. A sub-committee (Proff. Coetzee, De Kock, Van der Walt, Dr Conradie and Mr Els) was appointed to investigate the matter and report back at the Closing Meeting.

Prof. De Kock raised the issue of the date of future conferences; with some universities now starting their academic year earlier, it was difficult to adhere to the consitution's requirement to hold conferences in the last week of the summer vacation

Matier, report to conference, items 4-6.

Cilliers 1968.

Also VC to S, 21 January 1969, in defence of the system. 
of the university whose academic year started the earliest. ${ }^{58}$ After considering the July vacation as an alternative, it was decided to schedule conferences in the last week of January or the first week of February.

Prof. Dietrich, convener of the sub-committee for the publication of textbooks by local scholars, presented his report on the local editions of text-books. His survey of Greek and Latin courses at South African universities had revealed that for Greek I each lecturer preferred his/her own course; for Greek II the main fare was Homer, Euripides, Plato, Demosthenes and Herodotus, for which the available British editions provided insufficient help; the same applied to Greek III, where some of the above re-appeared, with the addition of Aristophanes and Sophocles.

For Latin I the authors were Cicero, Pliny, Sallust, Vergil and Catullus, who were adequately served by existing editions; in the case of Latin II, where Horace, Livy, Sallust, Roman comedy, Cicero and Vergil figured, the available editions were acceptable, but were lacking in literary appreciation; for Latin III, Tacitus, Lucretius and Juvenal were well served, but Terence, Plautus and Seneca not. He suggested different authors from the traditional ones: Apuleius, Cornelius Nepos, Florus, Flaccus, Lucan and an Early Latin reader. ${ }^{59}$ He was requested to continue with the project.

A sub-committee (Proff. Coetzee, Naudé and Van Rooy) was appointed to look into the matter of specific themes at conferences and report back at the Closing Meeting. Another sub-committee (Proff. Van Rooy and Naudé) was asked to re-open arrangements for the visit of Prof. Dihle.

The Chairperson reported that membership had reached 250 and that the regional branches were active. ${ }^{60}$ Special mention was made of the activities of the new Port Elizabeth and Grahamstown branches.

The Association had been represented at the 12th annual meeting of FIEC in Geneva in September 1966 by Mrs Els, who had submitted a report to the secretary. ${ }^{61}$ Proff. Davis, Dietrich and Pope had read papers at the first International Conference for Mycenaeology at Rome in September and October 1967, which Ms Baumbach had also attended. Prof. Kitto's visit had been a great success: he lectured at various universities and his wife gave some piano recitals.

Prof. Naudé presented the report on Acta Classica. Since no report had been presented at the 1966 conference, this report was very detailed and covered the period 1964-1969. In July 1967 Prof. Viljoen had resigned as Managing Editor and been succeeded by Prof. Gonin. Thanks were expressed to Prof. Viljoen, who had held the position since $1959 .^{62}$

Also VC to S, 21 January 1969.

Dietrich to Smuts, 14 November 1968, tabled at conference.

A table of the growth of membership in the different categories from 1964 to 1967 was published in $N L 12.3$ (1967) 22-23.

61 See Els 1967.

62 A letter of thanks was also sent by the outgoing secretary: Baumbach to Viljoen, 17 June 1969. 
A survey of the costs of each volume of Acta Classica was presented.

- Volume VII (1964) had cost R968, including R68 for footnotes and Greek font, and R51 for corrections. Despite donations from most of the universities (R295) and advertising (R134), a deficit of R275 was reflected.

- Volume VIII (1965) had cost R1050, with a deficit of R299 (donations from universities R416, advertisements R60).

- The cost of Volume IX (1966) had climbed to R1180 and the deficit to R447 (donations from universities R450, advertisements R90).

The publication of Volume $X$ (1967) had been delayed due to the change of editorship and the amount of Greek font required. The volume appeared together with Volume XI (1968) in December $1968 .^{63}$ Final accounts were not yet in, but it was estimated that the volumes would cost R1164 (deficit R672; donations R300, advertisements R90) and R1444 (deficit R949, donations R260, advertisements R60) respectively. The rolling deficit had been reduced by the annual grant of R400 (R600 for the larger Vol. XI) from the National Council for Social Research and intermittent grants from the central treasury (the last, R100, in 1965). The meeting decided to pay R100 per year to Acta Classica retrospectively for the period 1966-1968. ${ }^{64}$ To meet rising costs of printing the selling price of Acta Classica would have to be raised to R5 per volume ${ }^{65}$ and the subscription of full members to R6 per annum. Editorial processing was to be speeded up and costs of corrections reduced by drawing up a guide for contributors. The number of periodicals received in exchange for Acta Classica now stood at $34 .{ }^{66}$ Photocopies of articles in these periodicals, housed in and administered by the library of Unisa, would be provided free of charge to members.

Reports of the regional branches were tabled and would be published in Newsletter. The financial statement revealed a credit balance of R2525. ${ }^{67}$ Eleven papers were read, each followed by a discussion introduced by a previously delegated person. A symposium on the role of prose composition and unseen translation in the Latin syllabus was also held. ${ }^{68}$

At the Closing Meeting on 31 January 1969 there were 26 members present. The Association was informed of a statement by Chief Justice L.C. Steyn, who had come out strongly in favour of the retention of Latin for lawyers. ${ }^{69}$ The new Executive Committee was to consist of Prof. De Kock (C), Prof. Coetzee (VC), Ms L Theron (S), Mr Simpson (T), Ms Baumbach (AM). As liaison officers for the universities were appointed Dr Conradie (Stellenbosch), Mr Matier (Rhodes), Mr Botha (Port Elizabeth), Mr W J Henderson (Natal), Mr Barkhuizen (Orange Free State), Mrs

\footnotetext{
63 Notice was given of delayed publication: Van Rooy to S, 11 November 1968.

64 Baumbach to C, 7 May 1969.

65 Notification of increase and updated distribution lists sent to Balkema, Hasse to Baumbach, 3 April 1969; 9 April 1969; Baumbach to Balkema, 17 April 1969; Baumbach to Els and Simpson, 18 April 1969.

66 Cf. Hasse 1966a, b, c; 1967a, b; 1968; 1969a, b.

67 Minutes of Opening Meeting, 28 January 1969.

$68 \quad$ Summaries in Smuts 1969b. See also Lewis 1969 and Simpson 1969.

69 Minutes of Closing Meeting, 31 January 1969, item 7(d).
} 
Shillington (Witwatersrand), Dr Kriel (Pretoria), Prof. Naudé (Unisa), Mr Saddington (Rhodesia), Mr Els (Fort Hare), Mr P J N. Snijman (Western Cape), Prof. Van der Walt (Zululand), Mr Cipolla (University College for Indians) and Mr J Scholtemeijer (University College of the North).

The new Editorial Committee of Acta Classica would consist of Prof. Gonin (Managing Editor), Prof. De Kock (Chairperson of CASA, ex officio), Prof. Naudé (Treasurer), Mr Hasse (Assistant), with Proff. Carney (Manitoba), Coetzee (Potchefstroom), Davis (Witwatersrand), Dietrich (Rhodes), Dilke (Leeds), Goold (Harvard), Paap (Cape Town), Smuts (Stellenbosch), Van Rooy (Unisa), Prof. Louw, and Mr W Henderson (Natal) and Dr Nicolaides (Johannesburg) as collaborators.

After much debate, the matter of the pool system was postponed to the next conference. The sub-committee on themes for future conferences recommended that two days of the conference be devoted to a specific theme. The final form of the programme was left to the in-coming committee. A proposal by Prof. Naudé that, in order to save time and money, notices, minutes, financial reports and other correspondence should be written alternately in English and Afrikaans was accepted.

The following motions were passed: that the editorial committee of Acta Classica restrict articles published in Acta Classica to work of a purely academic nature (original research, Forschungsberichte, and, from time to time, invited review articles); that Newsletter be considered the publication of the Association in which articles of a more popular nature should appear, without excluding purely academic articles; that in view of the increased costs in the publication of Acta Classica, the annual subscription of full members be raised to R6, and of Life Members to R72; that, instead of $25 \%$ of subscription paid, regional branches would in future receive R1 for full members, 30c for associate members and 15c for student members; and that the Constitution of the Association be brought up to date, incorporating changes made at past conferences, and that copies of the revised constitution be sent to all members.

An invitation by Prof. Erasmus, extended at the previous conference in 1966, for the next conference to be held at the University of Port Elizabeth in 1971, was accepted, with Cape Town as second, and the Rand Afrikaans University as third choices. A special word of appreciation and thanks was expressed to Prof. Haarhoff, who, in spite of poor health, had travelled from Cape Town and delivered a paper. It was suggested that microphones should be used at conferences and that contact between the different universities be promoted by reciprocal lectures. All agreed that the arrangement whereby delegates were accommodated in a university residence had contributed greatly to the success of the conference. ${ }^{70}$

Prof. Van Rooy, who would be in Germany at the time, would represent CASA at the Assemblée Générale of FIEC in Bonn on 30-31 August 1969 and then also attend its International Conference on 1-6 September 1969 at his own expense. ${ }^{71}$

Minutes of Closing Meeting, 31 January 1969.

Minutes of Closing Meeting, 31 January 1969, item 7(a): an amount of R30 was voted towards his expenses; Ernst to C, 17 January 1969 (notice, invitation and report on FIEC for 1968); notice in $N L 14.2$ (1969) 19. The maximum contribution made available to Prof. Van Rooy was subsequently raised to R50; Baumbach to C, 7 May 1969. 


\subsection{Administration 1969-1971}

\subsubsection{General}

The plans to produce the new letterhead using the head of the nymph Terina depicted on a 5th century stater were finally brought to fruition. ${ }^{72}$ The usual transfer of information and documents from previous to new secretary (correspondence, reams of unused cyclostyle paper and wax sheets) was effected. ${ }^{73}$

After some delay caused by the change of treasurer, the FIEC subscription (still NF 100, or \$20 per annum) was paid for the next two years (R29.32). ${ }^{74}$ Prof. Van Rooy represented CASA at the general assembly of FIEC in Bonn on 30 August $1969 ;^{75}$ he also attended the International Conference of the Federation on 1-6 September $1969 .^{76}$

The Association was again invited to send a report on its activities for publication in Proceedings of the Classical Association of Great Britain. The editor and Joint Hon. Secretary, Dr Landels, reported on their AGM, gave the date and venue of the next conference (7-10 April 1970, at Bangor, North Wales) and extended an invitation to South African classicists to attend. Dr Landels expressed the wish "to increase communication between our Associations and the Allied Associations overseas." The information was passed on to the new secretary of CASA, and the report sent to Dr Landels for inclusion in Proceedings. The suggestion was made that the two associations exchange periodicals; and it was possible that Ms Baumbach, $\mathrm{Mr}$ Atkinson, Prof. Dietrich and Ms Lewis would be in a position to attend the conference at Bangor. ${ }^{77}$

\subsubsection{Visitors}

Prof. Kathleen Atkinson (née Chrimes, Queen’s University, Belfast) visited Rhodes University in 1969 (unfortunately too late to attend the national conference) ${ }^{78}$ On 24 March she gave a public lecture on "Reflections on the Roman rule of law" which was arranged by the Department of Extra-Mural Studies at the University of Cape Town. Dr Robert Ogilvie (Balliol College, Oxford) was the Visiting Hofmeyr Fellow at the University of the Witwatersrand during 1969, and gave some lectures at Rhodes

72 T to S, 22 March 1969; T to Se, 4 August 1969; approved by Executive Committee, Minutes of Meeting, 14 March 1970. This is still the Association's logo.

73 Baumbach to S, 10 August 1969.

74 Durry to C, 19 February 1969; Baumbach to C, 7 May 1969; T to S, February 1970?

75 Report and financial statement to C and S, 26 November 1969; see Van Rooy 1970a. The final claim was for R25.50 (R5.50 for single trainfare Leiden-Bonn; R14.00 for two nights at a hotel in Bonn; and R6.00 for four meals). Misunderstanding concerning attendance at the general assembly and/or international conference elicited a request from the treasurer for clarification of future policy. T to S, undated (February 1970?).

76 See Van Rooy 1970b.

77 Landels to Baumbach, 10 May 1969; Baumbach to S, 10 June 1969; Baumbach to Landels, 11 June 1969 (including report); Landels to Baumbach, 25 June 1969.

78 Naudé to S, 5 November 1968. There was still the possibility of her reading a paper at the conference: Naudé to S, 13 November 1968; C to S, 14 November 1968. 
University and the University of Natal. ${ }^{79}$ Mrs Hilda Coppens-Ide (Rijksuniversiteit, Gent) offered to give lectures on programmed learning: new tendencies in the didactics of Latin (and Greek) during a visit to South Africa in 1969. The various regional branch secretaries were informed. Mrs Coppens was invited to address the Western Cape Regional Branch at its meeting in August. ${ }^{80}$ In the event a revised programme was drawn up in which provision was made for lectures at Cape Town (4 September), Stellenbosch (6-7 September) and Bloemfontein (15-16 September). ${ }^{81}$ Prof. C A Trypanis (Oxford) gave lectures at Rhodes University and the University of Natal.

\subsubsection{Acta Classica}

At a meeting of the Executive Committee on 20 June 1970, the relation between the journal's finances and the central treasury was raised and another meeting scheduled to discuss the issue. The Treasurer tabled a memorandum in which it was proposed that the two systems should merge, and that the central treasury manage the journal's finances. The main arguments for this view were that it would eliminate duplication, better serve members' interests since the annual grant from the National Council for Social Research should benefit all members (e.g. in keeping subscription fees low), and reflect a unified image of the Association (e.g. in a single financial report). Problems arose from the existing practice of voting ad hoc payments at biennial conferences; the varying amounts and dates of payment caused confusion and misunderstanding. There was uncertainty as to whether the journal was to be supported when the need arose or should fend for itself. The editorial committee would be able to function more efficiently if it worked according to a realistic annual budget submitted to the Executive Committee. Short-falls could then be anticipated and corrected before publication and the biennial conference. A summary of the escalating printing-costs against membership fees revealed a lack of correlation:

$\begin{array}{lll}\text { Year } & \text { Subscription } & \text { Printing-cos } \\ 1965 & \text { R5.00 } & \text { R } 968.60 \\ 1966 & & \text { R1097.79 } \\ 1967 & & \text { R1358.03 } \\ 1968 & & \text { R1538.65 } \\ 1969 & \text { R6.00 } & \text { R1939.25 }\end{array}$

While the printing-costs had doubled in the five years, the subscription had only been increased by $20 \%$. During the same period, the average cost to the central treasury had risen by R7 per member. However, increasing the subscriptions was not the only option: if the quotation of the publisher of Acta Classica, A A Balkema, could not be

\footnotetext{
79 Announced at the conference: Minutes of Closing Meeting, 31 January 1969, item 7(c).

80 Coppens-Ide to Baumbach, 28 May 1969, forwarded to S; Baumbach to S, 10 June 1969; to Coppens-Ide, 11 June 1969.

81 Coppens-Ide to S, 15 July 1969.
} 
kept within the limits of the budget, an alternative publisher should be found. A new system of financing the journal was proposed: donations from the Research Council and universities could still be sollicited, but would be paid into the central treasury; the treasurer and chairperson of the Executive Committee would be co-opted onto the editorial committee of Acta Classica to draw up a budget; the central treasury would handle all accounts; an amount would be made available for the administrative costs of the editorial committee; a single financial report for the two-year period would be tabled at the biennial conference; the Association's funds could accumulate sufficiently to be accessed for a special edition of Acta Classica on its 25th annniversary; and the financial burden on the treasurer of the journal would be alleviated, while the increased load on the central treasurer would require secretarial help. ${ }^{82}$ It was suggested that the matter be brought up at the forthcoming conference. ${ }^{83}$

\subsubsection{Newsletter/Akroterion}

The Newsletter, which started life in 1956 as a few cyclostyled pages intended to maintain contact between the Department of Latin at the University of Stellenbosch and its former students, had grown into an important instrument in the context of the teaching of Classics in South Africa. ${ }^{84}$ Though still edited, administered and published by the above department, it was accepted as an official publication of the Association and received an annual subsidy. In 1970, in a new format, it was renamed Akroterion. The name was chosen to signify the geographical location ("cape") and the vantage-point from which the local and international Classical scene would be viewed (“height”, “pinnacle”). ${ }^{85}$

\subsubsection{Next conference}

Arrangements for the next conference were characterised by a flood of speedily delivered and answered correspondence. Looking back from an age of e-mail on the one hand and snail-mail on the other, one is filled with admiration and awe.

A tentative invitation was received to hold the 1971 or 1973 conference in collaboration with the Classical Association of Central Africa at the University College of Rhodesia, Salisbury. The invitation was acknowledged with thanks, but the invitation from the University of Port Elizabeth for 1971 still stood; it was also mentioned that there might be practical problems for the project. ${ }^{86}$

$82 \quad$ Memorandum of T, undated (1970).

83 Coetzee to C, 22 January 1971.

84 I trust the reader will excuse a personal recollection concerning the early production of Newsletter. As an undergraduate student in 1956-1958, I was among the students who were roped in whenever a new number of Newsletter was to be assembled. The cyclostyled pages, in their stacks, were laid out in sequence on a long table. Prof. Smuts, his colleagues and the students would then line up and proceed in measured order around the table, each collecting pages to form a set. These would then be stapled, and the process repeated until the edition was complete.

85 See Smuts 1970.

86 Saddington to C, 28 February 1969; C to Saddington, 14 April 1969; Saddington to C, 9 June 1969. Postponement to 1975 was later suggested: Saddington to C, 3 August 1970; Saddington to S, 10 December 1970. 
A meeting of the Executive Committee was held in Johannesburg on 14 March 1970 to deal with conference arrangements. The date of the next conference, at the University of Port Elizabeth, was fixed for 26-30 January $1971 .^{87}$ A memorandum, drawn up by Proff. Van Rooy, Naudé and Maurach, was tabled at a meeting of the Executive Committee. It provided a scheme for a programme around a particular theme. ${ }^{88}$ The second day (Wednesday, 27 January) would be devoted to the main theme of the conference: the development of organic structure in Greek literature. A prominent classicist from Europe would be invited to attend the conference and deliver the opening address; failing this, Prof. Maurach would be invited to fill this role. Further lectures would be invited on organic structure in Greek literature (lyric, history), from which four of 30-45 minutes each were to be selected for inclusion in the programme (one after the opening address, two in the afternoon, and one in the evening). A speaker would be designated to summarise the day's proceedings. An analagous programme, this time on Latin literature (Vergil), was suggested for the third day (Thursday, 28 January), with the difference that there would be three lectures (one after the introductory address and two in the evening) so as to leave the afternoon free for an excursion. Day four (Friday, 29 January) would be open for lectures on various topics or the conference theme (two in the morning and two in the afternoon). It was also proposed that the lectures on the conference theme be published in an extended edition of Newsletter and that speakers be notified of this. The Closing Business Meeting would be held on Saturday, 30 January. ${ }^{89}$ This was the first formal deviation from the original conception regarding programming since the first conference in 1956, where three lectures of one hour each, with 30-45 minutes of discussion were laid down as the norm. ${ }^{90}$ The number of papers delivered at conferences had varied between 7 and 11; provision was now being made for 13 .

A budget of R500 for a foreign speaker was also submitted and the eleven universities were asked to contribute R50 each. An additional R250 was earmarked for the costs of publishing the papers. ${ }^{91}$ Three universities declined to contribute, ${ }^{92}$ while three others offered contributions on certain conditions. ${ }^{93}$ The scheme was abandoned $^{94}$ and Prof. Maurach invited to give the two introductory papers. ${ }^{95}$

\footnotetext{
87 Letter of thanks for the invitation, S to Du Plessis, 16 March 1970.

88 For the motivation, see Henderson 2004:106.

89 Memorandum and Minutes of Executive Meeting, 14 March 1970.

90 See Henderson 2004:91.

91 S to Acting C (Coetzee), 24 March 1970 (English and Afrikaans).

92 Registrar (Potchefstroom) to Acting C, 26 May 1970; Registrar (Pretoria) to Acting C, 3 June 1970; Registrar (Stellenbosch) to Acting C, 4 June 1970.

93 The University of the Witwatersrand offered to contribute R50 on condition that the visitor spent four days at the university (Deputy Registrar to Acting C, 5 June 1970; acknowledged, S to Registrar, 25 June 1970); the University of the Orange Free State made a donation of R50 towards the publication costs only (Registrar to Acting C, 5 June 1970; acknowledged, S to Registrar, 25 June 1970); the Rand Afrikaans University offered R50, but reserved final judgement until the identity of the visiting scholar was known (Registrar to Acting C, 19 June 1970); Unisa also offered R50 to be used for publication costs in Akroterion or as an appendix to Acta Classica (acknowledged, S to Van Rooy, 25 June 1970; Van Rooy to S, undated; S to Van Rooy, 8 October 1970). 
A letter was sent to the editor of Newsletter concerning the proposal to publish the papers on the conference theme. ${ }^{96}$ Although the editor agreed in principle with the idea, he was hesitant to publish papers on the proposed theme of structural analysis or on specialised topics; according to a conference decision, Newsletter was to cater for more popular articles, which would be of use and interest to school teachers as well as academics, and not material that was more suitable for Acta Classica; further thought was required on this matter, and also on the process of refereeing, final editing and date of submission. ${ }^{97}$ The Executive Committee decided to leave the publication of conference papers to the personal choice of the speakers themselves. ${ }^{98}$

The University of Port Elizabeth withdrew its invitation to host the next conference, and the other options were investigated. The University of Cape Town, though willing, was faced with the problem of two members of the Classics Department being on sabbatical leave (Ms Baumbach and Mr Atkinson) and one about to depart for Holland (Prof. Hugo). The other options were ruled out by the Executive Committee: Salisbury would entail too many difficulties at such a late stage, and the Rand Afrikaans University, still housed in temporary buildings, did not yet have the necessary facilities. ${ }^{99}$ The University of the Witwatersrand was approached and indicated its willingness to host the conference. ${ }^{100}$ A month later there was still uncertainty about the venue. ${ }^{101}$ Finally, Cape Town reaffirmed its ability to host the conference. Prof. Hugo would finalise as much as possible before his departure, and Ms Baumbach, despite still being on leave, would take over the reins. ${ }^{102}$

The Executive Committee met at the Rand Afrikaans University on 20 June 1970 to discuss arrangements for the conference. When too few offers of papers had arrived before the cut-off date (10 May), specific persons were approached for inclusion on the programme. ${ }^{103}$ By August there were a few too many offers of papers, but these were accommodated in slots vacated by cancellations. ${ }^{104}$

$95 \quad$ S to Maurach, 4 August 1970.

$96 \quad$ S to Smuts, 16 March 1970.

97 Smuts to S, 24 March 1970.

$98 \quad$ S to Smuts, 25 June 1970.

99 Baumbach to S, 27 March 1970; S to Registrar, UCT, 1 April 1970; S to Hugo, 17 April 1970; S to Paap, 17 April 1970; Paap to S, 21 April 1970; Hugo to S, 26 April 1970; telegram Du Plessis to S, 8 June 1970; reply S to Du Plessis, 9 June 1970; Hugo to S, 21 September 1970; S to Hugo, 28 September 1970.

100 S to Davis, 28 April 1970; Davis to S, 4 May 1970.

101 S to Du Plessis, 25 May 1970; S to Hugo, 25 May 1970.

102 Hugo to S, 28 May 1970; telegram Hugo to S, 29 May 1970; accepted, S to Hugo, 2 June 1970. S to Davis, 2 June 1970; S to Hugo, 28 September 1970; Baumbach to S, 5 November 1970.

103 S to Kriel, Van Rensburg, Paap, Wakerley, 25 June 1970; Wakerley to S, 12 August 1970 (declining); Van Rooy to S, 11 August 1970; S to Austin, 30 September 1970; Austin to S, 5 October 1970.

104 Cancelled: Van Rooy to S, 11 August 1970 (eventually replaced on programme); Scholtemeijer to S, 5 January 1971; S to Scholtemeijer, 13 January 1971; Davis to S, 7 January 1971; S to Davis, 13 January 1971; telegram Van der Walt to S, 15 January 1971. Included: S to N Austin (Rhodesia), 4 September 1970; S to Raven, 15 October 1970; Raven to S, 21 October 1970. On stand-by: S to Chapman, 15 October 1970; S to M Arnheim, 19 October 1970 (both finally included in the programme). 
Formal invitations were sent to the Honorary Presidents, Prof. Haarhoff, whose health prevented him from attending, ${ }^{105}$ and Prof. Petrie, who was entering his 90th year, and made his apologies on the grounds of his increasing deafness which precluded him from benefitting from the contributions. ${ }^{106}$ Other invited dignitaries responded positively, promising to attend if circumstances permitted and requesting copies of the programme: the Honorary Vice-President, Dr Muller; Chief Justice Steyn; the Greek Ambassador, His Excellency Mr M C Economides; and Prof. Viljoen. ${ }^{107}$ Letters of appreciation, together with copies of the programme, were sent to each. ${ }^{108}$ The Italian Ambassador would have been glad to attend, but was due to leave South Africa before the time. ${ }^{109}$ Invitations were also sent to Mr S Theron (Director of Education, Cape), Dr W K du Plessis (Director of Higher Education), Mrs S Lloyd (Principal's Liaison Officer, UCT), Prof. W Schaffer (Assistant Principal: Academic), Mr G Bizos (Chairman, SAHETI, Johannesburg) and $\mathrm{Mr}$ Balkema (publisher of Acta Classica). ${ }^{110}$

The final arrangements for the conference (travel routes, numbers of delegates, accommodation, venues, facilities, dates, reception, excursion, transport, publicity) proceeded apace. ${ }^{111}$ A special effort was made to designate suitable persons to introduce the discussions on the papers. ${ }^{112}$

\subsection{The Regional Branches}

\subsubsection{The Western Cape Region}

The branch held a conference on Cicero at the University of Cape Town on 19 April 1969. The main speakers were Mr Atkinson ("Cicero the politician”), Prof. Smuts ("Cicero the philosopher") and Prof. Hugo ("Cicero the orator"). In the afternoon $\mathrm{Mr}$ J Juritz (Department of Physics) gave a talk on "Space physics: the Greek scientists and their heirs". On 7 June a conference on Vergil was held at the University of Stellenbosch. On this occasion Mrs Maras (née Bruwer) spoke on “The fourth book

\footnotetext{
105 S to Haarhoff, 16 October 1970; Haarhoff to S, undated.

106 S to Petrie, 16 October 1970; Petrie to S, 27 October 1970.

107 Muller to S, 23 October 1970; Steyn to S, 23 November 1970; Economides to S, 25 October 1970; Viljoen to S, 28 October 1970.

$108 \mathrm{~S}$ to dignitaries, 12 December 1971.

109 A Paveri-Fontana to S, 23 October and 5 December 1970.

110 Paap to S, 14 January 1971; S to Theron, Du Plessis, Lloyd and Schaffer, 18 January 1971; S to Bizos and Balkema, 21 January 1971. Apologies for absence were received from both directors (22 and 24 January 1971), but Prof. Schaffer would attend the buffet supper and some of the sessions: Schaffer to S, 23 January 1971.

111 S to Hugo, 17 November 1970; Hugo to S, 20 November 1970; S to Hugo, 1 December 1970; Hugo to S, 4 December 1970; Paap to S, 12 and 14 January 1971; S to Paap, 15 January 1971; Baumbach to S, 17 January 1971; S to Baumbach, date obscured; Baumbach to S, 18 January 1971.

112 Arnheim to S, 29 October 1970; S to Louw and Baumbach, 1 December 1970; Baumbach to S, 6 December 1970 .
} 
of Vergil's Aeneid", and Mr Apthorp on "Aeneid Book Four in the Aeneid as a whole".

A refresher course for teachers of Latin was held in collaboration with the Cape Education Department and the University of Stellenbosch from 7 to 11 July 1969 at the university. The conference was well advertised and delegates were invited from all over South Africa. ${ }^{113}$ The opening address by Dr G J J Smit (Director of Education) was followed by fourteen papers and a symposium on the aims and methods of teaching Latin. In addition, there were practical demonstrations of the structural method (Mr C S Heyneke), of handling a piece of Ciceronian prose (Ms Baumbach), of the language laboratory and audio-visual aids; a film show and exhibition of books; and a talk on ancient music (Prof. Pulvermacher). ${ }^{114}$

The last conference of the year took place at the University of Cape Town on 13 September. A symposium on "The poems of Catullus" was introduced by Prof. Smuts, Dr Conradie, Misses Baumbach and J A Yeld. Mr Potgieter and Prof. Hugo spoke on the epigrams of Martial. The new committee was then elected: Mr Powis (C), Dr Conradie (VC), Miss Yeld (S), Miss A Gordon (Assist. S-T), Proff. Smuts and Hugo, Mrs M J Els, Sr O’Sullivan and Messrs Potgieter and D J Rousseau $(\mathrm{AM}) .{ }^{115}$

\subsubsection{The Eastern Cape Region}

The annual general meeting of the Grahamstown Branch was held at Rhodes University on 7 March 1969. The new office-bearers were elected: Prof. Dietrich (C), Mr Hewitt (VC), Mr Matier (S-T), Mrs Dietrich, Mrs Jenkins, Prof. Cattenéo and Messrs Chalmers and Turner (AM). Mr Matier then reported on the CASA conference at Potchestroom. The activities of the branch were spread over the year: a lecture by Prof. Kathleen Atkinson on "The education of the lawyer in Ancient Rome”, in conjunction with the Law Society (9 April 1969); a production of Plautus' Menaechmi by Mr Hewitt (10-12 April); Latin Verse Reading Competition for schools (6 June); a talk by Mr Chalmers on "Unseen translation: an analysis" (8 August); a lecture by Prof. C A Trypanis on "Oedipus at Colonus" (22 August); the annual "presidential” address by Mr Hewitt, "The world of Pliny the Younger" (17 September); and a public lecture by Dr Ogilvie on "the traveller in Antiquity", who also gave stimulating lectures to staff and students on Livy, Horace and Roman religion. ${ }^{116}$

\subsubsection{The Natal Region}

Three meetings were held in 1969: the first, in Durban, consisted of a discussion of the new syllabus led by Mr G E Smith; at the second, in Pietermaritzburg on 24 May 1969, Mr Whiteley, substituting for an indisposed Dr Margaret Wakerley (University

\footnotetext{
113 Announced at the conference: Minutes of Closing Meeting, 31 January 1969, item 7(b); also Hugo 1968; Smuts 1969a.

114 See the special edition of NL 14.3/4 (1969).

115 Report of Yeld to S, 14 April 1970.

116 Notice from Matier, 18 February 1969; report to S, undated.
} 
of the Transkei) ${ }^{117}$ gave a witty talk on Vergil's use of adjectives; and at the third, held in Durban, Dr Wakerley presented a travel talk with slides and Mr W Henderson gave a talk on Classical lyric poetry. The branch had 65 registered members, but had had a disrupted year at committee level: Mr Chapman had resigned as secretary, to be replaced by Dr Wakerley; Mr Henderson had been appointed to the Rand Afrikaans University and was replaced as Chairperson by Mrs F P (Barbara) Bristowe. ${ }^{118}$ Further branch reports were due to be tabled at the forthcoming conference.

\section{BIBLIOGRAPHY}

Bauer, G 1970. Perhaps a method of teaching Latin. Akroterion 15.1:17-20.

Benade, J T 1966. "Report on the colloquium on the Classics in education 1965” - 'n bespreking. NL 11.4:9-18.

Cilliers, J F G 1968. Die Klassieke Vereniging van Suid-Afrika: Streektak van die OVS. NL 13.4:13, 21.

Editor, 1966. Verslag oor die Klassieke Vereniging van Suid-Afrika. Februarie 1965Julie 1966 (English en face). AClass 9:158-163.

Els, M J 1967. Verslag van die 12e Algemene Vergadering van die Internasionale Federasie van Klassieke Verenigings. NL 12.1:26-30.

Hasse, P 1966a. Jongste ruiltydskrifte - 'n oorsig (6). NL 11.1:20-23.

Hasse, P 1966b. Jongste ruiltydskrifte - 'n oorsig (7). NL 11.2:42-45, 6.

Hasse, P 1966c. Jongste ruiltydskrifte - 'n oorsig (8). NL 11.4:20, 8.

Hasse, P 1967a. Jongste ruiltydskrifte - 'n oorsig (9). NL 12.1:22-25.

Hasse, P 1967b. Jongste ruiltydskrifte - 'n oorsig (10). NL 12.2:23-24.

Hasse, P 1968. Jongste ruiltydskrifte - 'n oorsig (11). NL 13.2:28-31.

Hasse, P 1969a. Jongste ruiltydskrifte - 'n oorsig (12). NL 14.1:37-38, 23.

Hasse, P 1969b. Jongste ruiltydskrifte - 'n oorsig (13). NL 14.2:23-25.

Henderson, W J 1967a. An interpretation of Horace, Carmina 3.13, o fons Bandusiae. NL 12.1:8-13, 16-21.

Henderson, W J 1967b. Classical Association of South Africa: Natal Regional Branch. NL 12.4:11-15.

Henderson, W J 2004. The Classical Association of South Africa: April 1956-January 1961. Akroterion 49:89-109.

Henderson, W J 2005. The Classical Association of South Africa: February 1961-July 1966. Akroterion 50:109-123.

Hugo, A M 1968. Opknappingskursus vir Latynonderwysers: Stellenbosch, Wintervakansie 1969. NL 13.4:8-10; 11-13 (English).

117 Now the Walter Sisulu University.

118 Report by Bristowe (undated); see Whiteley 1969. Due to problems encountered in opening a building society account, the cheque from the central treasury to the branch for 1968 became invalid, and as an annual report was not submitted, the branch forfeited its allowance for 1969; Goodyer, Report to meeting, 2 May 1970; copy included, Wakerley to S, 12 June 1970. A renewed cheque for 1968 was issued (for the second time), but the forfeiture was upheld, in the light of the precedent of the Transvaal Branch, which had submitted its report too late and forfeited its grant for 1968; Kriel to T, 18 April 1969; Memorandum of T to S, June 1970. 
Kitto, H D F 1967a. The significance of the gods in Greek tragedy. NL 12.2:2-4.

Kitto, H D F 1967b. Drama in the life of Athens - an historical perspective. NL 12.2:5-8.

Kriel, D M 1967. Korrespondensie. NL 12.3:24-25.

Lewis, Bryna. 1969. The role of prose composition and unseen translation in the Latin syllabus. NL 14.1:24-27.

Mostert, D F. 1969. Die belang van Latyn vir die juris. NL 14.2:16-19.

Simpson, G. 1969. Latin prose composition. NL 14.1:28-34.

Smuts, F 1957. Retirement of Professor T J Haarhoff. NL 2.4:1-3

Smuts, F 1966a. Die Klassieke Vereniging van Suid-Afrika / The Classical Association of South Africa. NL 11.3:96-101.

Smuts, F 1966b. The Classics in the news. NL 11.4:21-22.

Smuts F 1967a. Konferensie van die Klassieke Vereniging van Suid-Afrika: Weskaaplandse Tak, Saterdag 3 Junie 1967. NL 12.2:9-15.

Smuts, F 1967b. Klassieke Vereniging van Suid-Afrika: Wes-Kaaplandse tak. NL 12.3:7.

Smuts, F 1967c. Editorial. NL 12.3:2,10, 23.

Smuts F 1967d. Non-literary Roman writers. NL 12.4:18-34 (including Latin extracts with translations).

Smuts, F 1967e. Wes-Kaaplandse streek: Konferensie: 21 Okt. 1967. NL 12.4:15-17.

Smuts, F 1968a. Editorial. NL 13.3:1-4, 26.

Smuts, F 1968b. Peregrinatio Americana. NL 13.3:5-16.

Smuts, F 1968c. Editorial. NL 13.4:1, 28.

Smuts, F 1969a. Refresher course for Latin teachers: 7-11 July, 1969. NL 14.1:2-3; 3-4 (Afrikaans).

Smuts, F 1969b. Klassieke Vereniging van Suid-Afrika: verslag van konferensie gehou te Potchefstroom 28 tot 31 Jan. 1969. NL 14.1:15-19; 20-23 (English).

Smuts, F 1970. Editorial. Akroterion 15.1:1-4.

Van Rooy, C A 1970a. Verslag van die Dertiende Algemene Vergadering van die Fédération Internationale des Associations d'Éudes Classiques (FIEC). Akroterion 15.1:30-35.

Van Rooy, C A 1970b. Die Vyfde Internasionale Klassieke Konferensie. Akroterion 15.2:21-24.

Viljoen, G van N 1966. Polemiek oor Latyn in die “Onderwysblad”. NL 11.4:19.

Whiteley, S 1969. Misadventures with a card-index. NL 14.2:8-12. 